Journal of

International Logistics and Trade

\title{
An Evaluation of the Korean Trade Adjustment Assistance (TAA) program
}

\author{
Insoo Pyo ${ }^{\mathrm{a}}$, Jacob Wood ${ }^{\mathrm{b}}$, Jungsuk Kim ${ }^{\mathrm{c} *}$ \\ ${ }^{\mathrm{a}}$ Bae, Kim \& Lee, LLC, Seoul, Korea \\ ${ }^{\mathrm{b}}$ Department of International Trade, Chungnam National University, Daejeon, Korea \\ ${ }^{\mathrm{c}}$ Institute of international and Area Studies, Sogang University, Seoul, Korea
}

\begin{abstract}
ARTICLE INFO
ABSTRACT

Article history:

Received 23 September 2016

Accepted 26 December 2016

This policy analysis examines the key issues involved in the Korean Trade Adjustment Assistance (TAA) program. As an important trade policy platform, this research details how the TAA provision targets impacted businesses and employees and documents the program's eligibility criteria and its evolution over time. The US TAA and EU EGAF programs are also

Keywords:

TAA

EGAF

Trade policy

Korea reviewed by detailing their respective strengths and their differences from their Korean counterpart. Finally, we document a range of areas where the Korean TAA initiative needs to be improved in order to best assist the firms and employees that have been negatively impacted by trade liberalization policy.
\end{abstract}

US

International trade

\section{The Korean Trade Adjustment Assistance (TAA) program}

As a country with a relatively aggressive trade liberalization policy agenda, the Korean government has taken a number of steps to insure that its ideological format is implemented as smoothly as possible. The implementation of an FTA-based agenda was difficult in Korea. Although Korea's main source of economic growth has been its trade of goods across international markets, Korea was also the last country in the world to maintain a rice quota. As such, the domestic FTA ratification process was quite difficult with some Korean politicians and opposition groups who supported the agricultural sector strongly opposing the FTAs. Thus, the TAA program was invented to provide support to those industries and people who had suffered or may suffer losses due to the FTAs. This "ideological format" was used as a means conflicting opinions among politicians in Korea who supported or opposed the FTA. A key initiative in this regard has been the introduction of the Korean TAA program. The primary responsibility of the system is to provide a compensation mechanism for those groups that have been affected or are expected to be adversely affected as a result of Korea's free trade agreements (FTA) or trade liberalization policies in general (Heo 2013).

Under the stewardship of the Ministry of Industry and Energy, the first draft of the TAA program was completed in August 2003. During the rounds of consultation and negotiation that followed, the policy format was first passed into law in April 2006, before being formally launched on April $29^{\text {th }}, 2007$. With an initial budget of 1.575 trillion won, the TAA program operated under the Trade Adjustment Support Center of the Small and Medium Business Corporation (SBC) of Korea. As part of this, a further 5.8 trillion won was allocated to assist eligible employees under the additional support from the Department of Labor and the Employment Information Center. In order for businesses or employees to receive support, the original criteria were considered too complicated and the eligibility criteria in particular were also very difficult to meet (Firms that are entitled to TAA are those that have experienced more than a $10 \%$ reduction in total

\footnotetext{
* Corresponding author: Institute of International and Area Studies, Sogang University, 35 Baekbeom-ro, Mapo-gu, Seoul, 04107
} Korea, Email: iias7@ sogang.ac.kr 
sales over the previous six months as a direct result of drastically increased imports from FTA partner countries). However, major amendments implemented in 2012 led to some improvements. Nevertheless, some commentators believe the eligibility criteria could be softened further. Under these new classifications (see Table 1), businesses were eligible to receive support (either financial or consultative services) if their sales or total production output had fallen by more than $10 \%$ (5\% in the case of sole trader). While employees were able to receive remuneration if their working hours had fallen by more than $30 \%$, as a result of increased import competition from an FTA trading partner. For an organization to apply for TAA it must operate in either the manufacturing or service industries (some exceptions may apply) and have been in business for more than 2 years.

Table 1. Standard for support of the enterprises

\begin{tabular}{lll}
\hline Classification & When affected & Degree of impact \\
\hline $\begin{array}{l}\text { When you were affected } \\
\text { by trade liberalization } \\
\text { policy. }\end{array}$ & $\begin{array}{l}\text { Within 2 years of your } \\
\text { request being made. }\end{array}$ & $\begin{array}{l}\text { The total sales or production output has decreased by more than } 10 \%{ }^{*} \\
\text { compared to the same period last year. Or if the impact alters business profits, } \\
\text { employment levels, the rate of operation or stock price by similar levels. }\end{array}$ \\
\hline $\begin{array}{l}\text { When you are sure that } \\
\text { you will be affected by } \\
\text { the policy in the future. }\end{array}$ & $\begin{array}{l}\text { Within 1 year of your } \\
\text { submission. }\end{array}$ & $\begin{array}{l}\text { When total sales or production output decreases by more than 10\% } \\
\text { months' over a 6 } 6\end{array}$ \\
& $\begin{array}{l}\text { alters business profits, employment levels, the rate of operation or stock price } \\
\text { by similar levels. }\end{array}$ \\
\hline
\end{tabular}

* Sole trader: more than $5 \%$

Source: The Trade Adjustment Support Center of SBC (Small and Medium Business Corporation), Korea.

The purpose of this paper is to review and analyze the current TAA Program in Korea and to provide a series of governmental policy suggestions. Given Korea's strong need for international trade as a means of achieving economic growth, the country has been successful in its bid to achieve a number of significant FTA agreements, including the Korea-US FTA, the Korea-EU FTA and the Korea-China FTA. Nevertheless, these agreements have also seen the Korean TAA program introduced as a means of compensating some sectors that have experienced economic losses caused by FTAs. However, since its introduction many scholars and trade practitioners have criticized the limitations of the current TAA program. As such, our paper addresses these concerns by making a series of suggestions which we believe may make the program more successful moving forward.

Financial assistance is offered to businesses by the Development and Promotion of the Small and Medium Business Fund. The loans offered help businesses purchase equipment up to the value of 4.5 billion won, while other work-related capital requirements can receive up to 500 million won. The calculated interest rates for these loans are adjustable and are set at levels that are $0.15 \%$ below the specified market rate. In addition to this, businesses also have access to a range of consultancy services. The contents of which are aimed at improving both the abilities of management and the skills and knowledge of employees. To this end, businesses may be allocated up to 40 million won, an amount which must be less than $80 \%$ of the total required expenses. In the 7 year period following the official introduction of the program in May 2007 until March 2014, the government investigated 105 cases, of which 82 were deemed eligible for financial assistance. From these, 21.8 billion won was offered by way of discounted loans, while a further 806 million won was provided for consultancy services (see Table 2).

Table 2. Total TAA expenditure (Unit: billion won)

\begin{tabular}{lrrrrrrrrr}
\hline Classification & 2007 & 2008 & 2009 & 2010 & 2011 & 2012 & 2013 & 2014 & Total \\
\hline Loan & - & 0.200 & 0.500 & 0.850 & 0.200 & 1.485 & 8.299 & 10.320 & 21.854 \\
Counseling & - & - & 0.032 & 0.016 & 0.016 & 0.159 & 0.251 & 0.332 & 0.806 \\
\hline
\end{tabular}

Source: Trade Adjustment Support Center of SBC of Korea

Table 3. Number of applications for TAA assistance

\begin{tabular}{lccccccccccc}
\hline Division & 2008 & 2009 & 2010 & 2011 & 2012 & 2013 & 2014 & 2015 & 2016 & Total \\
\hline Application & 3 & 3 & 2 & - & 13 & 31 & 28 & 22 & 3 \\
Injured Firms & 2 & 3 & 2 & - & 8 & 24 & 25 & 17 & 1 & 82 \\
Uninjured Firms & 1 & - & - & - & 2 & 4 & 1 & 1 & - & 9 \\
Withdrawn /returned & - & - & - & - & 3 & 3 & 2 & 4 & - & 12 \\
\hline
\end{tabular}

Source: https://www.ktc.go.kr:20443/statsTotal.do. (Access date: 29 August 2016)

After the program was established, 3 requests were made in each of 2008 and 2009; however, by 2015 this number had grown to 22 (see Table 3). Over the 2007-2014 period 105 applications were made due in large part to the 35 
applications (56\% of all cases during the period) that were made following the implementation of the Korea-EU FTA, which came into force in 2011. Of those industries affected, the pork processing, clothing, cosmetics, and a range of other sectors were significantly impacted (See Appendix Table A1).

\subsection{Modifications to the Korean TAA program}

As noted earlier, the TAA program in Korea has undergone relatively constant change since it was first implemented, most significantly in 2012, when a number of amendments were made to enhance its scope and make the program more accessible to business. The Korean government eased the eligibility requirements and offered additional service provisions that include sole owner operators. Bureaucratic elements were also streamlined with documentation requirements minimized, the specifics of which are documented in Table 4 . On the whole, these adaptations had a positive impact on the program. The number of applications increased significantly after 2012 to $87.9 \%$ of all reported cases (during the 2008-2014 period) occurring in 2013/2014 and, of these, some $81 \%$ were successful in their bid for TAA.

Table 4. Comparison of before and after revisions to the law

\begin{tabular}{|c|c|c|c|}
\hline & Classification & Before 2012 revision & After 2012 revision \\
\hline \multirow[t]{4}{*}{$\begin{array}{l}\text { Changes } \\
\text { to criteria }\end{array}$} & $\begin{array}{l}\text { Requirement for } \\
\text { eligibility for TAA } \\
\text { program }\end{array}$ & $\begin{array}{l}\text { Total sales or production output has } \\
\text { decreased by } 20 \% \text { over a } 6 \text {-month } \\
\text { period, compared year on year }\end{array}$ & $\begin{array}{l}\text { Total sales or production output has decreased by } \\
10 \% \text { over a } 6 \text {-month period, compared year on year }\end{array}$ \\
\hline & Program governance & $\begin{array}{l}\text { Program governance: Ministry of } \\
\text { Strategy and Finance (Chairperson: } \\
\text { Minister for the Ministry of } \\
\text { Strategy and Finance) }\end{array}$ & $\begin{array}{l}\text { Program governance: Ministry of Trade, Industry } \\
\text { and Energy (Chairperson: Minister for the Ministry } \\
\text { of Trade, Industry and Energy) }\end{array}$ \\
\hline & $\begin{array}{l}\text { Trade adjustment } \\
\text { support center }\end{array}$ & $\begin{array}{l}\text { Dealt with applications, request and } \\
\text { Project Management }\end{array}$ & $\begin{array}{l}\text { Additional document preparation support, i.e., proof } \\
\text { of negative trade impact on business }\end{array}$ \\
\hline & Application Procedure & 4 kinds of documents needed & 2 kinds of documents needed \\
\hline \multirow[t]{2}{*}{$\begin{array}{l}\text { New } \\
\text { provisions }\end{array}$} & $\begin{array}{l}\text { Inclusion of sole } \\
\text { owner operators }\end{array}$ & & $\begin{array}{l}\text { Support provided to sole owner operators that have } \\
\text { experienced sales or production output decreases of } \\
5 \% \text { over a } 6 \text {-month period, compared year on year }\end{array}$ \\
\hline & $\begin{array}{l}\text { Consultancy support } \\
\text { to improve } \\
\text { international business } \\
\text { competitiveness }\end{array}$ & $\begin{array}{l}\text { Eligibility requirement: Total sales } \\
\text { or production output has decreased } \\
\text { by } 20 \% \text { over a } 6 \text {-month period, } \\
\text { compared year on year }\end{array}$ & $\begin{array}{l}\text { Eligibility requirement: Total sales or production } \\
\text { output has decreased by } 5 \% \text { over a } 6 \text {-month period, } \\
\text { compared year on year }\end{array}$ \\
\hline
\end{tabular}

Source: Authors' own summary

In addition to 2012 amendments, the processing mechanisms associated with a TAA application were modified in 2015. This was in response to a series of complaints that the support procedures were too complicated and a burden for smaller businesses in particular. As a consequence of these changes, the process was streamlined with oversight of the application process now falling under the jurisdiction of SBC of Korea (See Appendix Table A2-2). Prior to this, the initial aspects of a TAA inquiry were managed by the SBC, while the investigation and final decision-making elements were conducted by the Commerce Commission. Lastly, the maximum period of credit was extended from 3 to 5 years and the loan limit that had been set at $150 \%$ of total sales was abolished, although the 4.5 billion-won limit was still kept.

Since its inception, the TAA program has endeavored to support both businesses and employees that have been negatively impacted by Korea's trade liberalization agenda. However, to date the TAA initiative has failed to deliver the necessary assistance required. So far, the TAA program has only had a minor effect ${ }^{\mathrm{a}}$ on structurally reforming uncompetitive firms' to raise their business performance. Moreover, the program has used taxpayer revenue inefficiently. In addition, the program's content is very similar to existing remedial initiatives that have been designed to support medium and small enterprises. Due to these issues and the overall lack of effectiveness, many have argued that Korea's TAA program has failed as a remedial tool. Low interest rate loans used to finance business operations seem even less efficient in the modern era of already historically low interest rates. The inefficient use of resources in this manner can ultimately lead to problems such as moral hazard or adverse selection ${ }^{\mathrm{b}}$. In an attempt to promptly resolve these problems, we suggest changing the measures that support at-risk firms by providing performance-based

a Evaluating the performance of TAA so far, the higher share of the aid went to fund firms' operations or facility maintenance rather than to enhancing the business structure or financial soundness of firms. The attribution of TAA to workers discharged by the FTA is almost negligible.

b To meet the TAA's genuine goals of facilitating the FTA process, the provision of assistance must focus on market efficiency and strengthening of the market structure. 
incentives to small and medium businesses. In addition to this, supplemental consultation services are required to help at-risk firms focus on their strengths and key areas of advantage while also adhering to the rules of openness and fair competition. New measures need to be considered such as matching-fund systems to tackling the various side effects of trade liberalization policy. Maintaining the current system of easing eligibility conditions or increasing the number of supported firms with increased loans is likely to exacerbate inefficiency concerns which may then yield unintended and detrimental consequences.

The Korean TAA system can be described as a form of industrial policy that aims to consolidate the capabilities of manufacturing and related industries and extend the type of financial and technical support that small and medium firms' need (Jeon and Cheong 2010). Despite improvements being made to its functionality, many argue that the TAA initiative has failed to deliver the type of support needed by businesses and employees. From an operational perspective, critics note that the program is indistinguishable from the types other provisions offered by the SBC.

Objective evaluation of the TAA's achievements in the past five years suggests its inability to fulfill its primary objectives. Nor could it serve as an appropriate tool for enhancing domestic FTA negotiations. As a result of its poor performance history, the Korean Government needs to consider the program's future. Even if the TAA system continues to exist, it should be transformed into employee-focused program rather the continuing its current firm-oriented policy emphasis (Heo 2013). In addition, its primary financial focus meant that it was unable to provide the type of manager or consultative assistance many firms needed while support for affected staff was also deemed by many to be inadequate. To elucidate the characteristics and problems of the Korean program, analyzing the policy experiences of the US TAA initiative is insightful.

Table 5. Summary of the main contents of US TAA

\begin{tabular}{llll}
\hline Classification & TAA for Workers(TAAW) & \multicolumn{1}{c}{ TAA for Firms (TAAF) $\$$} & TAA for Farmers (TAAF) $^{*}$ \\
\hline Time of Introduction & \multicolumn{1}{c}{ Trade Expansion Act of 1962 } & Trade Act of 2002 \\
\hline Managing Department & $\begin{array}{l}\text { Department of Labor } \\
\text { Employment \& Training } \\
\text { Administration } \\
\text { (DOL ETA) }\end{array}$ & $\begin{array}{l}\text { Economic Development } \\
\text { Administration } \\
\text { (EDA) }\end{array}$ & $\begin{array}{l}\text { Foreign Agriculture Service of } \\
\text { the Department of Agriculture }\end{array}$ \\
\hline Implementing Agency & $\begin{array}{l}\text { Department of Labor } \\
\text { Employment \& Training } \\
\text { Administration }\end{array}$ & $\begin{array}{l}\text { Trade Adjustment Assistance } \\
\text { Center (TAA Center) }\end{array}$ & $\begin{array}{l}\text { Local Farm Service Agency } \\
\text { Service Center } \\
\text { (LOcal FSA Service Center) }\end{array}$ \\
\hline An annual Budget & \$656 million & S16 million & \$90 million \\
\hline Assistance Contents & $\begin{array}{l}\text { Income support, Vocational } \\
\text { training, Support the costs of } \\
\text { looking for a job or moving } \\
\text { costs, Medical insurance, Tax } \\
\text { deduction services }\end{array}$ & $\begin{array}{l}\text { Technical support and financial } \\
\text { assistance to help improve firm } \\
\text { competitiveness }\end{array}$ & $\begin{array}{l}\text { Technical and financial support } \\
\text { (up to \$12,000) }\end{array}$ \\
\hline
\end{tabular}

Note: Budgets for TAAW and TAAF reflect 2014 estimations, while the TAAF figures are for 2013.

Source: Park (2014) and Collins (2014), McMinimy (2014), Bolle (2015), Hornbeck (2013)

$\uparrow$ Trade Adjustment Assistance for Workers. The confines of this program also include the Alternative Trade Adjustment Assistance (ATTA) and Trade re-adjustment Allowance (TRA) initiatives. The ATAA initiative is similar to the Re-Employment Trade Adjustment Assistance (RTAA) program, which was adopted in 2011. The RTAA is a supportive system which helps subsidize the costs of hiring employees that are 50 years of age or older. The TRA is a subsidy-based system offered to the workers who complete a certain level of education requirement. The details are explained in Table 6.

+ Trade Adjustment Assistance for Firms

* Trade Adjustment Assistance for Farmers (TAAF). The assistance offered to farmers was introduced in 2002 as part of the Trade Act.

\section{The US Trade Adjustment Assistance (TAA) program.}

In 1962, US President John F. Kennedy oversaw the introduction of the Trade Expansion Act (TEA). Within the confines of the legislation, was a TAA program that would offer technical and managerial assistance to organizations that had sales or production levels adversely affected by the government's trade liberalization policy agenda. The program provided assistance to manufacturing firms and employees and was supported by the American Federation of Labor and the Congress of Industrial Organizations (AFL-CIO). However, unlike the Korean version of the TAA which provides the vast majority of its funds to firms as well as workers, the primary focus of its American predecessor is to support those workers who face unemployment or are in danger of becoming unemployed in the future. The worker-oriented focus of the program meant that most of the budget allocation was aimed at improving the welfare of affected staff, while financial assistance for firms plays only a minor role (see Table 5).

After its initial manufacturing sector emphasis, the scope of the program was extended to include the farming sector 
when the Bipartisan Trade Promotion Act was revised in 2002. In this instance, the Ministry of Agriculture and Forestry provided technological and financial support to firms involved in the farming and fisheries sectors that had experienced significant income losses as a result of greater import competition. In addition, training and educational opportunities as well as job-searching assistance were also offered as a means of equipping those that had been adversely affected with the tools they need to re-enter the workforce. Further amendments were made to the TAA program with the inclusion of service industry and public sector workers under the provisions set out in the American Recovery and Reinvestment Act (ARRA) of 2009. However, as economic conditions deteriorated in the wake of the global financial crisis, the US government was called upon to make further legislative changes. This led to the creation of the Trade Adjustment Assistance Extension Act of 2011 which saw TAA support withdrawn for public sector workers.

With an ambition to not only minimize the effects of market failure, but also provide opportunities for social equality, the US TAA program has played an important role in helping the US achieve other trade policy objectives. Acting as a bargaining chip, the program has helped to mitigate the threat posed by protest groups, and thereby aided the US in establishing a more liberalized trade policy platform. The expansion of the TAA program in 2002 was also a pivotal factor behind a Congressional decision to approve the Trade Promotion Authority later that same year.

\subsection{An analysis of the US TAA programs}

The Korean TAA program has a relatively short history, having only been established in 2006. In order to evaluate it properly, we need to compare it with the similar programs that have been adopted elsewhere, such as the US TAA program. The US TAA Program, which was introduced in 1962, has been revised several times. Since its inception, the US TAA program has been relatively successful and as such can provide some insight into how the Korean Government can further improve its own TAA program. The Trade Adjustment Assistance for Firms (TAAF) offers technical and consultancy advice for managers whose firms have experienced declines in sales or production output as a result of US trade liberalization policy. It also provides a support mechanism for firms whose employees have been laid off or at risk of unemployment (up to 50 staff or $5 \%$ of the total workforce). The level of financial assistance that is allocated to the TAAF program is small, accounting for around 3\% of the total TAA budget. Nonetheless, the role it plays is significant. With a goal to improve the efficiency and competitiveness of negatively impacted businesses, the TAAF offers businesses technical and strategic support so that these firms are better prepared to meet the demands of an increasingly complex domestic marketplace. Under the guidance of the Economic Development Administration, the program seeks to equip managers with the skills they need to conduct better marketing, operational, and financial planning (see Table 6), rather than merely offering access to financial support.

Table 6. TAAF consultative support offered in 2014

\begin{tabular}{llrrr}
\hline Classification & Contents details & Firms & Rate $^{\text {Cost }^{\mathrm{c}}}$ \\
\hline Finance & Improvement accounting system, Cost management system, Automatic Data & 17 & $5 \%$ & $\$ 279,655$ \\
& Processing System (ADPS) & & \\
Management & Establishment of enterprise strategy planning, Stabilize the company, & 25 & $7 \%$ & $\$ 715,000$ \\
& Business management & 129 & $38 \%$ & $\$ 4,193,630$ \\
Marketing/Sales & Sales training, Market expansion and possibilities, Web site improvements & 94 & $27 \%$ & $\$ 3,069,677$ \\
Production & Production efficiency, New product development, Automatic production & 79 & $23 \%$ & $\$ 2,051,130$ \\
Backup System & Asset planning, Improving Management Information Systems, Computer & 730 & & \\
& management support, Supply chain assistance & &
\end{tabular}

Source: Bolle (2015)

The second key component of the TAA program in the US is the Trade Adjustment Assistance for Workers (TAAW) initiative. The TAAW platform provided training for manufacturing sector employees that had faced difficulties as a result of FTAs or other forms of open market policy. In order to be eligible for assistance, workers need to have been either laid off or faced the real prospect of losing their job in the near future. All applications were managed by the Department of Labor Employment and Training Administration in a process that is highly efficient. For those affected, a range of services were offered, including vocational training, educational opportunities, and other recruitment provisions that would help them find employment. Additional support was also offered to workers aged 50 years and older (see Appendix Table A3 for more details). Of the two major programs offered (TAAF and TAAW), the TAAW service is by far the largest with expenditure far outweighing that of its counterpart (see Table 5). In 2012, of the $\$ 855$ million allocated for spending within the TAAW program, \$575 million was spent on vocational training and financial assistance packages. The remaining component of the budget was spent on the Trade Readjustment Allowance (TRA) (\$239 million) and the Reemployment Trade Adjustment Assistance (RTAA) (\$41 million).

\footnotetext{
c Costs include government assistance costs (about 52\%) and the charges of firms for stabilizing the company.
} 


\subsection{Legislative changes to the US TAA program}

In recent years, as the government responded to the demands of the 2008 financial crises, the US TAA program has experienced significant legislative change. Important elements in this regard, were the introduction of the Trade and Globalization Adjustment Assistance Act (TGAAA) and the American Recovery and Reinvestment Act (ARRA) in 2009. These new acts extended the scope and parameters of the TAAW initiative to include employees from not only the manufacturing sector but also those working in the service and public sectors. As part of this, the level of financial support offered to affected firms was increased from $\$ 16$ million to $\$ 50$ million a year, while the criteria for assistance were also eased.

However, as the TGAAA was only a temporary legislative provision (that expired January 1, 2011), the TAA program was destined to undergo further refinements. These came firstly in the confines of the Omnibus Trade on December 2010, then more recently within the guidelines of the Trade Adjustment Assistance Extension Act (TAAEA) of October, 2011. Under the TAAEA, support was withdrawn from public sector employees, while other budgetary changes were made in an effort to reign in government TAA spending (see Appendix Table A3). Finally, in 2014, as the US economic recovery began to take shape, the government made moves to tighten up eligibility requirements; however, the scope of the program was increased to previous 2009 levels where public sector employees were again included (see Table 7). The amendments formed what ultimately became the Trade Adjustment Assistance Act (TAAA) of 2014. While the initial efforts by Sander Levin (D) and Adam Smith (D) to push through the legislation were unsuccessful, a compromise was met under the leadership of Sherrod Brown (D) which saw the TAAA passed and TAA program extended under law until 2020, where D represents Democrat Party.

Table 7. Characteristics of the US Trade Adjustment Assistance Act of 2014

\begin{tabular}{|c|c|}
\hline & Characteristics of legislation \\
\hline \multirow{2}{*}{$\begin{array}{l}\text { Applicable to } \\
\text { both employees } \\
\text { and firms }\end{array}$} & $\begin{array}{l}\text { At the time of calculating the impact an FTA had on production output and job security support should also be } \\
\text { offered to workers and firms that were impact of non-FTA trading partners. This was a specific attempt by } \\
\text { government to alleviate the impact that China had had on US industry. }\end{array}$ \\
\hline & $\begin{array}{l}\text { The Act included an expansion of the benefits to include firms and employees that were involved in not only } \\
\text { the manufacturing field but also the agricultural and fishing industries. }\end{array}$ \\
\hline \multirow{3}{*}{ Employees } & Unemployment benefits which had expired after receiving an education were to be extended again. \\
\hline & Extension of the Health Coverage Tax Credit (HCTC) which had expired in 2013. \\
\hline & $\begin{array}{l}\text { Expansion of the unemployment benefits. It was revised so that workers can now receive up to } \$ 1,500 \text { a month } \\
\text { in financial assistance. }\end{array}$ \\
\hline Firms & $\begin{array}{l}\text { The firm's support program turned back to } 2009 \text { levels. This now meant that firms outside the manufacturing } \\
\text { sector were now included such as the agricultural and fishing industries. }\end{array}$ \\
\hline
\end{tabular}

To summarize, from a Korean perspective, the US TAA program has been relatively successful because the utilization rate is comparatively higher than that of its Korean counterpart. Furthermore, the US TAA program is more consultative in nature whereas Korea's is more financial in terms of the direct financial support it provides to companies. Also we believe the main target of the US TAA program is affected workers, and not the companies as is the case with the Korean TAA. This is a key area of distinction that needs to be addressed within the structure of the Korean TAA so that it is able to transform itself from a program that offers short-term financial assistance to one that embraces a more long-term approach through the provision of consulting, education and training services.

Since it was first introduced in 1962, the US TAA program has provided an important support mechanism for businesses and staff impacted by trade liberalization policy ${ }^{\mathrm{d}}$. The financial and vocational support offered to employees has provided not only net social welfare gains, but also an important bargaining tool from which the threat posed by protest groups could be mitigated. These impacts undoubtedly assisted the US in establishing a more open market trade policy platform.

\section{EU European Globalization Adjustment Fund (EGAF) program}

While the US TAA program provides a form of direct assistance to those firms and employees who are negatively

\footnotetext{
${ }^{\mathrm{d}}$ We understand that the US TAA also has some limitations and may have not achieved all of its set objectives. However, compared to the Korean TAA program, we believe that the US TAA initiative has achieved significantly more than the Korean program and has had reasonable success in several key areas including trying to compensate workers and industries that have suffered from the trade liberalization, improving the effectiveness of government expenditures, and providing some tools for political negotiation process.
} 
impacted by trade liberalization policy, a new system called the European Globalization Adjustment Fund (EGAF) Program has been created in the EU. Prior to the establishment of the EGAF by the European Commission in 2006, the EU offered a basic assistance program called the "European Structural and Investment Fund" (ESIF), which provided a mechanism that aimed to resolve issues of inequality that existed among member countries, regions, and classes. In this instance, the ESIF program takes a strategic, long-term perspective by anticipating and managing the social impact of industrial change through activities such as life-long learning. Unlike the ESIF, the EGAF program provides support to people losing their jobs as a result of major structural changes in world trade patterns due to globalization or result of the global economic and financial crisis. These cases may include the closure of a large company or the movement of production facilities to outside of the EU. While the ESIF targets long-term issues such as educational training and changes in labor market dynamics, the EGAF provides assistance to those workers who have suffered unemployment due to the EU's aggressive trade liberalization policies by offering a range of service provisions such as counseling, careers advice, mentoring and training.

The EGAF program also finances a range of measures that assist affected individuals with looking for a job, career advice, educational training and re-training, mentoring and coaching, and entrepreneurship/business creation seminars. The program also provides individuals with training allowances, mobility/relocation allowances, subsistence allowances and other similar kinds of financial support. However, the EGAF does not co-finance social protection measures such as pensions or unemployment benefit. According to EGAF Regulation ${ }^{\mathrm{e}}$, self-employed, temporary workers and fixed-term workers that are made redundant from trade liberalization policies can receive support from the EGAF program with an annual budget of EUR 150 million allocated for the period of 2014-2020. In addition to this, the program is able to fund up to $60 \%$ of the costs associated with helping affected individuals find other employment opportunities or establish their own business.

In summary, the EGAF program has a couple of points relevant for improving the Korean TAA Program. First of all, the EGAF provides a certain strong signal to the related industries and workers facing possible losses from an increase in import competition as a result of the process associated with trade liberalization. It is very important for certain industries $^{\mathrm{f}}$ and workers to understand the pros and cons of trade liberalization ${ }^{\mathrm{g}}$. In particular, in order to achieve effective trade liberalization, it is very important to get support or a manageable level of opposition to trade liberalization from those industries and workers that face losses from an increase in import competition (Mah 2010, Kim and Lee 2012). As such, the EGAF Program provides a strong means of practical and psychological assistance to those parties in need. Secondly, the EGAF program uses a bottom-up technique which endeavors to cater for the needs of specific companies and industries that are suffering from trade liberalization. Thirdly, the EGAF provides regional support services to workers that have been laid off by offering a targeted regional plan that includes colleges, training institutions or consulting agencies. Finally, the EGAF also offers a detailed and comprehensive evaluation system which forms the cornerstone of any successful assistance program. As part of this system, the use of funds is also monitored, with the EGAF placing strict requirements on those that both seek and use the program.

\section{Summary and comparison of the Korean TAA, the US TAA and the EU EGAF}

The Korean TAA program was introduced in 2006 to compensate groups that have been affected or are expected to be adversely affected as a result of Korea's FTA policy. Although the Korean TAA program has been somewhat successful in assisting sectors such as the manufacturing and service industries, it has also drawn a range of significant criticisms from both industrial sector and academia because of the relatively rigid guidelines, small rate of acceptance, and the complex nature of preparing the relevant supporting documents. After revisions were made in 2012, the TAA program was adjusted to be a more flexible system and the number of cases for application since then has been increasing. However, the Korean TAA program still has some limitations. Much could be learned from similar programs offered in the US and Europe through their respective US TAA and EU EGAF initiatives. In particular, the US TAA has focused more on the issues of consultation, training, and educational opportunities while the financial assistance packages offered to the workers and companies have been relatively minor. In addition, the EU EGAF has also sought to provide counseling, career service, and educational programs to those individuals affected. In this sense, the Korean TAA program needs to place a greater emphasize on the areas of training, consulting, and education.

As discussed earlier, the Korean TAA program was initially introduced to compensate those sectors which may be adversely affected by the FTAs. As such, the program was set up to achieve a number of important goals including proper compensation, cost-effective government expenditure and the establishment of appropriate internal negotiation tools that could be utilized for specific political purposes. However, in the years following its initial inception, the

\footnotetext{
${ }^{\text {e }}$ EU Globalization Adjustment Fund Regulation, EU No 1309/2013 and repealing Regulation (EC) No 1927/2006.

${ }^{f}$ The EGAF fund was provided to the workers of companies such as Nokia, Air France and Saab. These certain industries, for example, can also refer to the automobile, mobile phone and aircraft manufacturing industries.

g Although freer trade can benefit exporters, consumers, and the economic system as a whole, it may create significant problems in certain sectors due to increased import competition.
} 
program was unable to meet its intended objectives and as a consequence it was revised in 2012 with significant amendments made to streamlining the application processes and expanding the scope of possible beneficiaries. However, in spite of these changes most industry practitioners and academic pundits criticized the program because of its limitations and ambiguous policy goals. Given such a critique, we believe that the Korean TAA program needs to target both workers and organizations in a way that is more long-term in nature.

While the US TAA program has a long history, having first started in 1962, it too has also undergone several rounds of improvisation. As it currently stands, the US TAA program has been set up to provide support to workers that have been impacted by trade liberalization policy by mainly focusing on offering consulting and education support services. Unlike the Korean program, which mainly focuses on providing financial support to small and medium size companies, the US TAA program provides a more basic level of support to those workers who have suffered or may suffer potential losses from US trade policy. Although some still criticize the merits of the US program, we believe that the US TAA initiative has been successful in achieving most of its fundamental objectives.

The EU EGAF was set up in 2006 to provide support to people who had lost their jobs as a result of major structural changes that were taking place in both the global trading environment and the global economic and financial crises. The EGAF also provides direct assistance through the provision of counseling, careers advice, and training to those workers who had become unemployed due to trade liberalization policy. Although there are still some commentators who want to revise the program, we need to take a look at some key attributes of the EU EGAF. In this instance, we believe that the EU EGAF program works as a means of providing strong support, both psychologically and practically, to those sectors that have been suffering. In addition, the detailed evaluation aspects of the EU EGAF program are another important factor behind its success.

In order for the Korean TAA to work more effectively, we believe that the Korean Government needs to closely examine the ways in which the US TAA and EU EGAF operate. Having conducting such a review, it may be apparent that the basic goals of the Korean TAA program may need to be clarified or amended. In addition to this, it may need to evolve from one that has an industrial policy base to one that provides a more direct means of supporting both companies and workers through the provision of consulting, education and training systems.

\section{Conclusion}

Since it was formally launched in 2007 , the TAA program has sought to alleviate the problems that FTAs have created for firms and employees alike. However, under its current format the program has not been able to achieve its stipulated goals of (i) providing proper compensation to some sectors suffering from the trade liberalization, (ii) establishing an effective and fiscally responsible government program, and (iii) offering tools that can enhance the political negotiation processes that are associated with trade policy. At the heart of the matter is the way in which the program is set up and operates. Critics argue that more needs to be done to improve the skills and capabilities of the firms themselves. As such, the Korean TAA program should do more than simply prop up uncompetitive declining industries through low-interest loans and other forms of financial assistance. It needs to be able to channel commercial activities in a way that provides the right types of incentives for businesses to innovate and upgrade their organizational models. As part of this, consulting services should be opened up to the market so that businesses offer the best kind of support possible. It is also imperative that procedurally, the eligibility criteria are not eased, nor should the level of financial support be increased, as changes to either aspect would only lead to increasingly inefficient results. In order to improve TAA program outcomes, it is important that future FTA negotiations take into consideration the actual costs the policy measures will have for businesses. This could be done by including opposition groups in both TAA and FTA policy discussions. Finally, in a bid to build a more effective compensation plan for firms and workers, several other initiatives could be adopted, including guaranteed wage insurance plans, additional unemployment and medical insurance benefits, and special education training provisions. In particular, it should be noted that the largest group of victims impacted by trade liberalization are the workers involved in industries that are specifically exposed to greater import competition. In order to help these workers to smoothly switch to other industries or companies, it is very important for the Government to provide a certain customized assistance to the workers. For this purpose, the current TAA program needs to be upgraded so that it is able to provide a greater degree of customized assistance.

In order to smooth out the domestic internal negotiation process, the TAA program should provide more of a facilitator role in the FTA rectification and enactment process. In this instance, officers or departments involved in the domestic negotiations will be able to draw on the use of a TAA program when facing domestic opposition to a particular FTA. Korea's economic growth, generally speaking, has come from its manufacturing sectors while its agricultural and service sectors have generally suffered economic losses from trade liberalization policy. As such, during the domestic negotiation process of ratifying FTAs in Korea, there has been strong opposition from people within the agricultural and service sectors that were strongly opposed to the FTAs. As a consequence of this, the process of ratification FTAs was often a painful and costly exercise. Consequently, the Korean TAA program was established as a means of mitigating the voices of discontent that existed with negatively affected industries.

By proposing to reimburse companies or sectors facing possible losses from an intensification in the level of import 
competition, the government will be able to obtain an agreement or at least silence the producer organizations or associations that take issue with Korea's trade liberalization policy agenda. By having reliable control systems over the preparation, implementation, and reimbursement processes of internal negotiation, the TAA program will be able to advance Korea's trade negotiations more effectively and as such achieve a higher level of economic efficiency by facilitating the necessary adjustment procedures. By doing this, the Korean Government will be better placed to mitigate any opposition it may face to trade liberalization legislation. In addition to assisting the manufacturing industry, the agricultural and service sectors should be eligible for TAA. Rather than repealing or downsizing the TAA program, it should be reformed in order to effectively deal with difficult FTA negotiations (Kim et al. 2016).

From an operational and management perspective, the Ministries of Trade, Industry and Energy, of Employment and Labor and of Strategy and Finance will need to collaborate if the government is to push forward with its medium to long-term goal of extending the TAA program to not only cater for the manufacturing and service industries but also the agricultural and public sector as well. Further administrative changes will also need to be streamlined in terms of not only how applications and documents are handled but also how individual cases are investigated. The latest 2015 legislative adjustments will go some way to overcoming some of these bureaucratic irregularities. However, as the dynamics of future mega-FTAs (RCEP and FTAAP) loom large on the horizon more reform will be necessary, particularly in the service sector where these kinds of deals are expected to have a significant impact.

\section{References}

Bolle, M.J., 2015. Trade Adjustment Assistance for Firms: Economic, Program, and Policy Issues. Congressional Research Service Report, Washington.

Collins, B., 2014. Trade Adjustment Assistance for Workers. Congressional Research Service, Washington.

Heo, Y., 2013. Assisting trade adjustment in Korea: Is it a facilitating device for FTA implementation?. Journal of International Logistics and Trade 11, 87-98.

Hornbeck, J.F., 2013. Trade Adjustment Assistance for Firms: Economic, Program, and Policy Issues. Congressional Research Service Report, Washington.

Jeon J and Cheong, I., 2010. An empirical study on the application of Korea's trade adjustment assistance program, Korea Trade Review 35, 1-22.

Kim, J.S., Ko, B., Heo, Y., Lee, J.H., 2016. Reshaping institutional arrangements for TPP ratification in Korea. Journal of Korea Trade 20, 167-185.

Kim, Y.K., Lee, J.H., 2012. A sensitivity analysis regarding the impacts of trade openness and globalization growth: Empirical evidence from Korea, Journal of International Logistics and Trade 10, 47-60.

Mah, J.S., 2010. The effect of export incentives on export promotion: The case of Korea, Journal of International Logistics and Trade $8,57-68$.

McMinimy, M.A., 2014. Trade Adjustment Assistance for Farmers. Congressional Research Service, Washington.

Park, J., 2014. TAA, FTA safety net, is it really safe: Current situation of using TAA and case study. Institute for International Trade, Trade Focus 13, 3-13. 


\section{Appendix}

Table A1. Offerings of TAA classified by FTA and product item ${ }^{\mathrm{h}}$

\begin{tabular}{|c|c|c|c|c|c|}
\hline FTA & Items & No. cases & FTA & Items & No. cases \\
\hline \multirow{3}{*}{$\begin{array}{c}\text { EFTA } \\
(3)\end{array}$} & LED Fixture & 1 & Korea-USA (1) & Wine & 1 \\
\hline & Wrist Watch & 1 & Korea-Singapore (1) & Petrochemical & 1 \\
\hline & Andong Salted Grilled Mackerel & 1 & \multirow{12}{*}{$\begin{array}{c}\text { Korea-ASEAN } \\
\text { (17) }\end{array}$} & Golf wear & 1 \\
\hline \multirow{19}{*}{$\begin{array}{c}\text { Korea-EU } \\
\text { (35) }\end{array}$} & Chocolate & 1 & & T-shirt & 3 \\
\hline & Purse & 2 & & Hiking boots & 1 \\
\hline & Pork and Pork Processing & 15 & & Footwear for sporting & 2 \\
\hline & Paint Hardener & 1 & & Dress shoes & 1 \\
\hline & Shampoo & 1 & & Women clothing & 1 \\
\hline & Cosmetics & 1 & & Cotton T-shirt & 2 \\
\hline & Hair dye & 2 & & Gloves & 2 \\
\hline & Paint & 1 & & Men's pants & 1 \\
\hline & Clay roof tile & 1 & & Lumber pallet & 1 \\
\hline & Automatic control panel, distributing boards & 1 & & Bag & 1 \\
\hline & Hair product & 1 & & Socks & 1 \\
\hline & Sunglasses & 1 & \multirow{6}{*}{$\begin{array}{l}\text { Korea-Chili } \\
\text { (6) }\end{array}$} & Sanmeoru Wine & 1 \\
\hline & Spring & 1 & & Pork processing & 1 \\
\hline & Mask pack seat & 1 & & Raspberry Wine & 1 \\
\hline & Heat exchanger & 1 & & Frozen squid & 1 \\
\hline & Cleansing Soap & 1 & & Pine lumber & 1 \\
\hline & Valve & 1 & & Frozen salmon & 1 \\
\hline & Glasses frame & 1 & \multirow{2}{*}{ Total } & \multirow{2}{*}{63 cases } & \\
\hline & Bearing for spinning machine & 1 & & & \\
\hline
\end{tabular}

Source: Korean Commerce Commission

Table A2-1. Procedure of the designation of the enterprises eligible for assistance in trade adjustment (current)

\begin{tabular}{|c|c|c|c|c|c|c|c|c|c|c|}
\hline \multirow[b]{2}{*}{ Enterprises } & \multirow{2}{*}{\multicolumn{2}{|c|}{$\begin{array}{c}\text { SBC } \\
\text { (Trade Adjustment } \\
\text { support center) }\end{array}$}} & & \multirow{2}{*}{$\begin{array}{l}\text { Ministry of } \\
\text { Trade, Industry } \\
\text { and Energy }\end{array}$} & \multirow[b]{2}{*}{$\rightarrow$} & $\begin{array}{l}\text { Commission of } \\
\text { Commerce }\end{array}$ & & \multirow{2}{*}{$\begin{array}{c}\text { Ministry of Trade, } \\
\text { Industry and } \\
\text { Energy }\end{array}$} & & \multirow{2}{*}{$\begin{array}{c}\text { SBC } \\
\text { (Trade } \\
\text { Adjustment } \\
\text { support center) }\end{array}$} \\
\hline & & & & & & $\begin{array}{l}\text { Deliberation of } \\
\text { Damages from } \\
\text { trade }\end{array}$ & $\rightarrow$ & & & \\
\hline \multirow[b]{2}{*}{ Request } & \multirow[t]{2}{*}{$\rightarrow$} & Receipt of & & & & SBC & & \multirow{2}{*}{\begin{tabular}{|} 
Designation of the \\
Enterprises \\
eligible for \\
assistance in \\
Trade Adjustment
\end{tabular}} & \multirow{2}{*}{$\rightarrow$} & \multirow[b]{2}{*}{$\begin{array}{c}\text { Consulting, loan } \\
\text { support }\end{array}$} \\
\hline & & $\begin{array}{l}\text { Application form, } \\
\text { sent to the Ministry } \\
\text { of Trade, Industry } \\
\text { and Energy }\end{array}$ & & $\begin{array}{l}\text { Notify to the } \\
\text { Commission of } \\
\text { Commerce }\end{array}$ & $\overrightarrow{(2)}$ & $\begin{array}{c}\text { Suitability } \\
\text { Confirmation of } \\
\text { Trade adjustment } \\
\text { program }\end{array}$ & $\rightarrow$ & & & \\
\hline
\end{tabular}

Table A2-2. Procedure of the designation of the enterprises eligible for assistance in trade adjustment (change)

\begin{tabular}{|c|c|c|c|c|c|c|c|c|}
\hline Enterprises & & $\begin{array}{c}\text { SBC } \\
\text { (Trade Adjustment } \\
\text { support center) }\end{array}$ & & $\begin{array}{c}\text { SBC } \\
\text { (Trade Adjustment } \\
\text { support center) }\end{array}$ & & $\begin{array}{l}\text { Ministry of Trade, } \\
\text { Industry and Energy }\end{array}$ & & $\begin{array}{c}\text { SBC } \\
\text { (Trade Adjustment } \\
\text { support center) }\end{array}$ \\
\hline Request & $\rightarrow$ & $\begin{array}{c}\text { Receipt of } \\
\text { application form }\end{array}$ & $\rightarrow$ & $\begin{array}{l}\text { Result of damage from } \\
\text { trade deliberation } \\
\text { Sending to Ministry of } \\
\text { Trade, Industry and } \\
\text { Energy }\end{array}$ & $\rightarrow$ & $\begin{array}{l}\text { Designation of the } \\
\text { Enterprises eligible for } \\
\text { assistance in Trade } \\
\text { Adjustment }\end{array}$ & $\rightarrow$ & $\begin{array}{c}\text { Consulting, loan } \\
\text { support } \\
* \text { Before loan support, } \\
\text { suitability confirmation } \\
\text { of Trade adjustment } \\
\text { program }\end{array}$ \\
\hline
\end{tabular}

\footnotetext{
h The totals documented reflect the number of cases until September 2014.
} 
Table A3. Overview of the US TAAW program

\begin{tabular}{|c|c|c|c|}
\hline \multirow{2}{*}{ Classification } & \multicolumn{3}{|c|}{ Contents of the TAA program } \\
\hline & 2002 & 2009 & 2011 \\
\hline $\begin{array}{l}\text { Targeted area of } \\
\text { support }\end{array}$ & $\begin{array}{l}\text { For manufacturing industry } \\
\text { workers who had been directly } \\
\text { or indirectly impacted by } \\
\text { increases in imports }\end{array}$ & $\begin{array}{l}\text { For manufacturing, service, and } \\
\text { public sector workers who had } \\
\text { been directly or indirectly } \\
\text { impacted by increases in imports }\end{array}$ & $\begin{array}{l}\text { For manufacturing and service } \\
\text { sector workers who had been } \\
\text { directly or indirectly impacted by } \\
\text { increases in imports }\end{array}$ \\
\hline \multirow{2}{*}{$\begin{array}{l}\text { Trade } \\
\text { Readjustment } \\
\text { Allowance (TRA) }\end{array}$} & $\begin{array}{l}\text { Additional financial support (up } \\
\text { to } \underline{104} \text { weeks) for workers } \\
\text { registered in full-time } \\
\text { vocational training }\end{array}$ & $\begin{array}{l}\text { Additional financial support (up } \\
\text { to } \underline{130} \text { weeks) for workers } \\
\text { registered in full-time vocational } \\
\text { training }\end{array}$ & $\begin{array}{l}\text { Additional financial support (up to } \\
104 \text { weeks) for workers registered } \\
\text { in full-time vocational training }\end{array}$ \\
\hline & $\begin{array}{l}\text { Additional financial support (up } \\
\text { to } \underline{130} \text { weeks) for workers } \\
\text { engaged in additional or } \\
\text { mandatory training }\end{array}$ & $\begin{array}{l}\text { Additional financial support (up } \\
\text { to } \underline{156} \text { weeks) for workers } \\
\text { engaged in additional or } \\
\text { mandatory training }\end{array}$ & $\begin{array}{l}\text { Up to } 156 \text { weeks, however supports } \\
\text { for the last } 13 \text { weeks is only offered } \\
\text { in order to complete the required } \\
\text { training standard }\end{array}$ \\
\hline $\begin{array}{l}\text { Training } \\
\text { Registration Period } \\
\text { (Requirements for } \\
\text { additional support) }\end{array}$ & $\begin{array}{l}\text { Within } 16 \text { weeks after dismissal } \\
\text { or within } 8 \text { weeks following } \\
\text { TAA approval }\end{array}$ & $\begin{array}{l}\text { Within } 26 \text { weeks after dismissal } \\
\text { or immediately following TAA } \\
\text { approval }\end{array}$ & $\begin{array}{l}\text { Within } 26 \text { weeks after dismissal or } \\
\text { immediately following TAA } \\
\text { approval }\end{array}$ \\
\hline Training Services & $\begin{array}{l}\text { Only possible for those doing } \\
\text { full-time training }\end{array}$ & $\begin{array}{l}\text { Full-time, Part-time (additional } \\
\text { pay for Trade re-adjustment } \\
\text { assistance is paid to those doing } \\
\text { full-time training) }\end{array}$ & $\begin{array}{l}\text { Full-time, Part-time (additional pay } \\
\text { for Trade re-adjustment assistance } \\
\text { is paid to those doing full-time } \\
\text { training) }\end{array}$ \\
\hline \multirow{5}{*}{$\begin{array}{l}\text { Reemployment } \\
\text { support system } \\
\text { A TAA (alternative } \\
\text { trade adjustment } \\
\text { assistance) }\end{array}$} & Workers aged 50 years or older & $\begin{array}{l}\text { Workers aged } 50 \text { years or older } \\
\text { who earn less than } \$ 55,000 \text { per } \\
\text { year }\end{array}$ & $\begin{array}{l}\text { Workers aged } 50 \text { years or older who } \\
\text { earn less than } \$ 50,000 \text { per year }\end{array}$ \\
\hline & $\begin{array}{l}\text { Needs to participate in TAA } \\
\text { approved training }\end{array}$ & $\begin{array}{l}\text { In the case of reemployment for a } \\
\text { regular or permanent position, } \\
\text { there is no need to participate in } \\
\text { TAA approved training }\end{array}$ & $\begin{array}{l}\text { In the case of reemployment for a } \\
\text { regular or permanent position, there } \\
\text { is no need to participate in TAA } \\
\text { approved training }\end{array}$ \\
\hline & $\begin{array}{l}\text { Someone who has been } \\
\text { unemployed for less than } 26 \\
\text { weeks and will be employed in } \\
\text { a permanent position }\end{array}$ & $\begin{array}{l}\text { Those employed in part-time } \\
\text { work of at least } 20 \text { hours a week } \\
\text { does not need TAA approved } \\
\text { training }\end{array}$ & $\begin{array}{l}\text { Those employed in part-time work } \\
\text { of at least } 20 \text { hours a week does not } \\
\text { need TAA approved training }\end{array}$ \\
\hline & $\begin{array}{l}\text { For someone who is paid less } \\
\text { than } \$ \underline{50,000}\end{array}$ & - & - \\
\hline & $\begin{array}{l}\text { Limited to } \$ 10,000 \text {, or } 50 \% \text { of } \\
\text { the difference between the new } \\
\text { and past wage for a maximum } 2 \\
\text { years }\end{array}$ & $\begin{array}{l}\text { Limited to } \$ \underline{12,000} \text {, or } 50 \% \text { of the } \\
\text { difference between the new and } \\
\text { past wage for a maximum } 2 \text { years }\end{array}$ & $\begin{array}{l}\text { Limited to } \$ 10,000 \text {, or } 50 \% \text { of the } \\
\text { difference between the new and } \\
\text { past wage for a maximum } 2 \text { years }\end{array}$ \\
\hline $\begin{array}{l}\text { Job Search } \\
\text { Allowance }\end{array}$ & $\begin{array}{l}\text { Supports up to } \underline{90 \% \text { of costs }} \\
\text { within a limit of } \$ \underline{1,250}\end{array}$ & $\frac{100 \% \text { support within a limit of }}{\$ \underline{1,500}}$ & $\begin{array}{l}\text { Supports up to } 90 \% \text { of costs within } \\
\text { a limit of } \$ 1,250 \text { (Implementation } \\
\text { is based on where the employee } \\
\text { works) }\end{array}$ \\
\hline $\begin{array}{l}\text { Relocation } \\
\text { Allowance }\end{array}$ & $\begin{array}{l}\text { Supports up to } \underline{90 \% \text { of costs }} \\
\text { within a limit of } \$ \underline{1,250}\end{array}$ & $\frac{100 \%}{\$ \underline{1,500}}$ support within a limit of & $\begin{array}{l}\text { Supports up to } 90 \% \text { of costs within } \\
\text { a limit of } \$ 1,250 \text { (Implementation } \\
\text { is based on where the employee } \\
\text { works) }\end{array}$ \\
\hline Tax refund & $\begin{array}{l}\text { Refundable tax deduction of up } \\
\text { to } 65 \% \text { of the monthly cost of } \\
\text { health insurance }\end{array}$ & $\begin{array}{l}\text { Refundable tax deduction of up to } \\
80 \% \text { of the monthly cost of health } \\
\text { insurance }\end{array}$ & $\begin{array}{l}\text { Refundable tax deduction of up to } \\
72.5 \% \text { of the monthly cost of health } \\
\text { insurance }\end{array}$ \\
\hline
\end{tabular}

Source: Hornbeck (2013) 